\title{
RUSSIA'S FOREIGN TRADE IN NOVEMBER 2014
}

\author{
N.Volovik
}

Russia's foreign trade key indicators plummeted in November 2014. The introduction of a "fiscal maneuver" in the oil and gas industry amid falling crude oil prices gave rise to substantial reduction in the crude oil export duty early in 2015. In an effort to set back such a price hike in the domestic grain market, the Russian Government took measures introducing export customs duties with a view to limiting Russia's wheat exports.

The World Bank's Global Economic Prospects ${ }^{1}$ published in January 2015 shows that global growth in 2014 was slower than it was originally expected, following the trends of the past few years. The World Bank reports that the global GDP in 2014 stood at 2.6\% against the previously anticipated growth rates by $3.2 \%$, and then by $3.4 \%$ in 2015 and by 3.5\% in 2016 . The new forecast shows that the global economy is expected to grow by $3 \%$ in $2015,3.3 \%$ in 2016 , and $3.2 \%$ in 2017.

While the U.S. economy has been gaining momentum, the economies of the EU member states and Japan are still awaiting growth. The United States is expected to see growth accelerate to $3.2 \%$ in 2015 (compared to $2.4 \%$ in 2014) and then subdue to $3 \%$ in 2016 and $2.4 \%$ in 2017. The European economics are anticipated to see a timid economic growth of $1.1 \%$ in 2015 (compared to $0.8 \%$ in 2014), up to $1.6 \%$ in $2016-$ 2017. Japan is projected to experience an economic growth up to $1.2 \%$ in 2015 compared to $0.2 \%$ in 2014 , with an acceleration of $1.6 \%$ in 2016 .

Some of the developing countries are expected to see their economic growth rates accelerate backed up by moderate crude oil prices, advancing U.S. economy, low global interest rates. Developing economies saw an economic growth rate of $4.4 \%$ in 2014 and the World Bank expects them to increase to $4.8 \%$ in 2015 and then reach 5.3\% in 2016 and 5.4\% in 2017. China is facing a guided slowdown in economic growth rates: following $7.4 \%$ growth in 2014 , with an outlook of growth by $7.1 \%$ in $2015,7 \%$ in $2016,6.9 \%$ in 2017.

Global trade flows in 2015 are expected to stay weak. Global trade growth subdued significantly following the global financial crisis: it increased less than 4\% in 2013 and 2014 while the pre-crisis growth rates averaged $7 \%$ annually. With high-income countries accounting for some $65 \%$ of global imports, the lingering weakening weakens both investment and consumer demand, having adverse impact on global trade recovery.

1 http://www.worldbank.org/content/dam/Worldbank/GEP/ GEP2015a/pdfs/GEP15a_web_full.pdf
The World Bank expects prices of exchange-traded commodities to retain moderate levels in 2015. The slump in crude oil prices in $\mathrm{H} 22014$ may improve the current account balances and budgets of oil-exporting developing countries. However, steadily low crude oil prices will weaken economic activity in exporting countries. For instance, the World Bank forecasts Russia's GDP to drop by $2.9 \%$ in 2015 and increase by as little as $0.1 \%$ in 2016 .

Russia's key foreign trade indicators saw a drastic fall in November 2014: the foreign trade turnover, calculated using the balance of payments methodology, amounted to $\$ 59,95 \mathrm{bn}, 27.3 \%$ below the value seen in 2013. At the same time, both exports and imports saw a substantial contraction. The volume of Russia's exports in November 2014 contracted by $21.7 \%$ to $\$ 36,7 \mathrm{bn}$ while imports dropped by $21.8 \%$ to $\$ 23,3 \mathrm{bn}$ compared with November 2013. Russia's trade surplus in November 2014 contracted by $19.3 \%$, to $\$ 13,4 \mathrm{bn}$ from $\$ 16,6 \mathrm{bn}$ compared with the values seen in November 2013.

In November 2014, global raw materials markets saw price mixed dynamics: some of non-ferrous metals started to rise as crude oil slid down.

By November 2014, both Brent crude oil prices and WTI prices marked five consecutive months of fall for the first time since the financial crisis in 2008. Crude oil prices hit 5-year lows after the OPEC decided not to reduce oil production output. The bottom wasn't hit yet: the prices kept falling in December 2014 and January 2015. On January 13, 2015 Brent crude oil spot price reached $\$ 45,13$ per barrel, hitting the lowest level since March 2009. In November 2014, the Brent crude oil average price was $\$ 78,44$ per barrel, 27.4\% lower than the price seen in November 2013. In the period between January and November of 2014, the price averaged $\$ 102,4$ per barrel, 5.5\% below the price seen in 2013.

In November, the average price of Russia's Urals crude oil was $\$ 78,33$ per barrel compared to $\$ 107,32$ in the previous year. Therefore, the price fell by $27 \%$. In the period between January and November of 2014, 


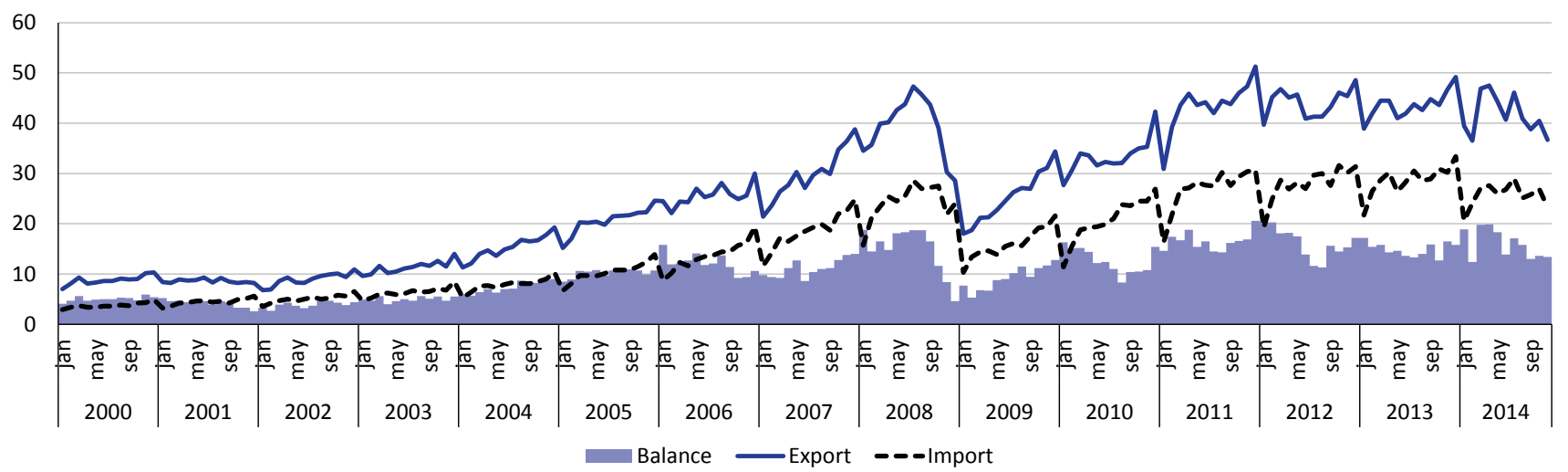

Source: the Central Bank of Russia.

Fig. 1. Russia's key foreign trade indicators (billions of US dollars)

the Urals crude oil average price dropped by $6.3 \%$ to $\$ 100,91$ per barrel compared with the price seen in the corresponding period of 2013.

Russia's President Putin signed on November 25, 2014 a Law Concerning the Amendments to Part 2 of the Tax Code of the Russian Federation and Certain Legal Acts of the Russian Federation, under which Russia embarked on a "tax maneuver" effective since January 1, 2015 in the oil and gas industry. The maneuver is intended to lower Russia's federal budget's reliance on export duties which have been reducing in response to falling crude oil prices. The maneuver provides for a stage-wise (over three years) reduction of export duties on crude oil (by 1.7 times) and oil products (by 1.7-5 times) on a commodity-specific basis. Mineral extraction tax rates for crude oil and natural gas liquids will increase by 1.7 and 6.5 times, respectively, over the same period. This will boost up crude oil prices in the domestic market, and hence the price of gasoline will go up. The maneuver provides for cutting the excise duty on gasoline and diesel fuel with a view to prevent a surge in the price of oil products inside the country.

The updated taxation scheme resulted in considerable reduction of oil export duties early in 2015 amid falling global crude oil prices. A monitoring shows that the average Urals crude oil price was $\$ 381,8$ per ton $(\$ 52,307$ per barrel) during the period beginning on the $15^{\text {th }}$ of December 2014 and ending on the $14^{\text {th }}$ of January 2015.

Hence, the crude oil export duty will be $\$ 112,9$ per ton from February 1, 2015, 33.7\% lower than that in January 2015. The preferential crude oil export duty on a few oil fields will be zero against $\$ 11,9$ per ton effective in January. This value developed because of updates in the duty rate calculation in the context of tax maneuver under which the duty becomes zero if the price is lower than $\$ 65$ per ton. The preferential export duty on high-viscosity oil will be some $\$ 14,2$ per ton in February compared to $\$ 22$ in January. In February 2015, the duty on commercial gasoline will be reduced to $\$ 88$ from $\$ 132,7$ per ton. The duty on light oil products and dark oil products will be $\$ 54,1$ per ton (compared with $\$ 81,6$ per ton in the previous month) and $\$ 85,8$ per ton (compared to $\$ 129,3$ per ton), respectively. The coke duty rate will decrease to $\$ 7,3$ per ton (compared with $\$ 11$ per ton in the previous month). The liquefied petroleum gas (LPG) duty will be set to zero from February 1, 2015 compared to $\$ 48,2$ in January.

The non-ferrous metals market saw mix price dynamics. According to the London Metal Exchange (LME), in November 2014 compared with November 2013 the price of aluminum increased $17.6 \%$, the highest value since December 2012. The price of nickel increased $15.5 \%$, whereas copper lost $5.1 \%$. In the period between January and November of 2014, the aluminum price rose by $0.4 \%$, the nickel price by $12.2 \%$, whereas the copper price dropped $6 \%$, relative to the corresponding period of 2013.

Copper prices fell because of increased glut of copper supply from Chile, Mexico, the United States, as well as weaker demand in China (some $47 \%$ of the world demand for copper), a stagnation in the European largest economies. Contraction in the aluminum and nickel stockpiles boosted the prices of these commodities.

In November 2014, the average value of FAO Food Price Index remained stable while prices of vegetable oils and grains increased, thereby offsetting the fall of prices of dairy products. The Index marked an average of 192.6 points, by 13 points or $6.4 \%$ lower than the value seen in November 2013. The dairy products price index dropped by $3.4 \%$ in November 2014 compared with the value seen in October and by $29 \%$ compared with the value seen in the previous year and marked 178.1 points, thereby reflecting an increase in the export supply of dairy products, while the share of imports shank in major markets such as China and the Russian Federation. The grains price index advanced by an average of $2.6 \%$ in November 2014 compared 
MONTHLY AVERAGE PRICES IN NOVEMBER IN THE PERIOD BETWEEN 2004 AND 2014

\begin{tabular}{|c|c|c|c|c|c|c|c|c|c|c|c|}
\hline & 2004 & 2005 & 2006 & 2007 & 2008 & 2009 & 2010 & 2011 & 2012 & 2013 & 2014 \\
\hline $\begin{array}{l}\text { Brent crude oil, } \\
\text { USD per barrel }\end{array}$ & 43.05 & 55.54 & 58.48 & 92.53 & 53.24 & 77.42 & 85.67 & 110.50 & 109.71 & 108.08 & 78.44 \\
\hline $\begin{array}{l}\text { WTI crude oil, } \\
\text { USD per barrel }\end{array}$ & 48.45 & 58.28 & 59.13 & 94.76 & 57.29 & 78.0 & 84.24 & 97.12 & 86.68 & 93.95 & 75.81 \\
\hline $\begin{array}{l}\text { Natural gas *, } \\
\text { USD/1million BTU }\end{array}$ & 4.96 & 7.46 & 8.99 & 9.47 & 15.81 & 7.81 & 8.59 & 11.32 & 11.83 & 11.42 & 8.9 \\
\hline $\begin{array}{l}\text { Copper, USD } \\
\text { per barrel }\end{array}$ & 3012.0 & 4060 & 7500 & 8008 & 4925.7 & 6675.6 & 8756.8 & 7551.8 & 7711.2 & 7070.7 & 6712.9 \\
\hline $\begin{array}{l}\text { Aluminum, } \\
\text { USD per barrel }\end{array}$ & 1822.8 & 1929 & 2659 & 2442 & 2121.4 & 1949.3 & 2596.3 & 2073.6 & 1948.8 & 1748 & 2055.6 \\
\hline $\begin{array}{l}\text { Nickel, USD } \\
\text { per barrel }\end{array}$ & 14483 & 12403 & 32348 & 30999 & 12140 & 16991 & 22600 & 17882 & 16335 & 13684 & 15807 \\
\hline
\end{tabular}

* The European market, average import border spot price.

Source: World Bank Commodity Price Data.

with the value seen in October and by $5.8 \%$ compared with the value seen in November 2013, and marked 183 points. The vegetable oils price index advanced by $0.7 \%$ to 164.9 points, but remains almost $17 \%$ below the value see in November last year.

In the period between January and November of 2014 Russia's trade turnover, according to the data provided by The Bank of Russia, amounted to $\$ 742,4$ bn, down $5.4 \%$ compared with the value seen in 2013. Exports contracted to $\$ 459$, 1 bn (down by $3.2 \%$ ), imports contracted to $\$ 283,3 \mathrm{bn}$ (down by $8.9 \%$ ). The balance of trade was positive, $\$ 175,7 \mathrm{bn}$, increasing $7.6 \%$ compared with the value seen in the period of January-November 2013.

Table 2 shows that exports increased only for the three groups of expanded range of commodities, namely food products and agricultural raw materials; timber and pulp and paper products; textile, textile products and footwear. The exports of other groups of commodities saw a contraction.
Exports of food products increased by virtue of substantially increasing export supplies of grains to foreign countries. According to the recent reports (as of November 26, 2014) of the Federal Customs Service of Russia, exports of grains in the 2014/2015 farming year amounted to 17682 thousand tons, including wheat (14 182 thousand tons), barn (2 536 thousand tons), corn (783,000 tons), other farm crops (181,000 tons). Grain exports in the $2014 / 2015$ farming year increased $22.8 \%$ compared with the previous corresponding period.

Supplies of timber and pulp and paper products to foreign countries increased basically by virtue of increased physical volumes of exported rough timber (by $10.1 \%$ ), worked timber (by 6.9\%), glued wood (by $10.7 \%$ ), paper pulp (by $2.9 \%$ ), newsprint (by $11.1 \%$ ).

Exports of the primary group of commodities fuel and energy commodities - contracted by virtue of shrinking physical volumes of exported crude oil (by $5.2 \%$ ) and natural gas (by $9.8 \%$ ), with their export

\section{CHANGES IN PRICE VOLUMES OF EXPORTS AND IMPORTS IN THE PERIOD BETWEEN JANUARY AND NOVEMBER OF 2014 (AS \% OF JANUARY-NOVEMBER 2013)}

\begin{tabular}{|c|l|c|c|}
\hline FEACN code & Commodity-production industry & Exports & Imports \\
\hline $01-24$ & Food products and agricultural raw materials (except textile materials) & 119.1 & 95.1 \\
\hline $25-27$ & Mineral products & 95.9 & 110.9 \\
\hline 27 & Fuel and energy commodities & 95.9 & 114.4 \\
\hline $28-40$ & Chemical industry products, rubber & 94.3 & 94.1 \\
\hline $41-43$ & Raw skins, fur skins and articles made thereof & 69.1 & 81.8 \\
\hline $44-49$ & Timber and pulp and paper products & 107.7 & 89.4 \\
\hline $50-67$ & Textile, textile products and footwear & 125.7 & 87.9 \\
\hline 71 & Precious gems, precious metals and articles made thereof & 83.7 & 120.1 \\
\hline $72-83$ & Metals and articles made thereof & 99.5 & 88.4 \\
\hline $84-90$ & Machinery, equipment and vehicles & 91.4 & 89.9 \\
\hline $68-70,91-97$ & Other commodities & 91.3 & 94.7 \\
\hline
\end{tabular}

Source: the calculations are based on the data provided by the Federal Customs Service (FCS) of Russia. 
prices falling (by $3.6 \%$ and $6.5 \%$, respectively). At the same time, exports of oil products increased $9.9 \%$ basically by virtue of increased (by $13.9 \%$ ) physical volumes of non-biodisel fuel supplies.

Imports contracted for all items of the extended nomenclature of commodities. Purchases of imported commodities increased only for the items covered by "Mineral Products" (by virtue of 2.9-fold increase in purchases of gasoline in physical terms and 3.1-fold increase in purchases of non-biodiesel liquid fuels) and "Precious gems, precious metals and articles made thereof".

The ruble's devaluation has made it advantageous to export grains to foreign countries, thereby triggering a price rise for domestic consumers. To prevent a drastic price rise in the domestic grains market, the Russian Government took measures introducing export duties which limit exports of Russia's wheat. The Russian Government Executive Order of December 25, 2014 No. 1495, Concerning Amendments to the Export
Customs Duties on Commodities Exported from the Russian Federation Outside the Territory of Customs Union Member Countries from February 1, 2015 thru June 30, 2015 introduced a wheat exports customs duty of $15 \%$ of the customs value plus 7,5 euro, but not less than 35 euro per ton.

The introduction of export duties will be the initial measure limiting exports of grains since 2010 when Russia had to introduce a total ban exports of grains because of a drought season, thereby triggering the price surge in global markets.

Some 20,1 million tons of wheat and meslin were exported to foreign countries in the period between January and November of 2014 , by $64.1 \%$ more than the value seen in 2013. Market participants expected limits on export of grains to be introduced as embargo as early as in the summer of 2014 , which could make it possible for them to refer to force majeure under agreements with buyers. No such reference is possible using the duties. 